\title{
Annual General Meeting
}

The 70th Annual General Meeting will be held in the Meeting Rooms of the Zoological Society of London, Regent's Park NW1, on Wednesday July $3 \mathrm{rd} 1974$ at $6 \mathrm{p.m}$. The Minister for the Environment, the Rt Hon. Anthony Crosland, MP, will be the speaker. A wine and cheese supper will be served for which tickets must be obtained in advance. Members are limited to one guest.

\section{Agenda}

1. Minutes of the Annual General Meeting 1973

2. Presentation and discussion of the Annual Report

3. Presentation and discussion of the Accounts and Auditors' Report

4. Election of the President

5. Proposed election of the Marquess of Willingdon as President Emeritus

6. Election of Officers

7. Election of Council Members

8. Vote of thanks to the Zoological Society of London

\section{Officers and Council}

The President, the Marquess of Willingdon, having stated his wish to resign, Council recommends the election of a new President and the re-election of other Officers of the Society for 1974-75:

President Professor Lord Zuckerman OM, KCB, DSc, FRS Chairman of Council Sir Peter Scott CBE, DSC Vice-Chairman of Council Lord Craigton PC, CBE Honorary Treasurer Ian D, Malcolmson TD Honorary Secretary Richard Fitter

Three members of Council retire at the Annual General Meeting and are not eligible for re-appointment for one year:

\author{
G. T. Corley Smith CMG \\ Tam Dalyell MP \\ Hon. Ivor Montagu
}

Council has appointed the following to fill these vacancies and their names are submitted for confirmation:

Dr G. C. L. Bertram

Dr David Harrison

Dr E. Barton Worthington 